Click www.researchjournal.co.in/online/subdetail.html to purchase.

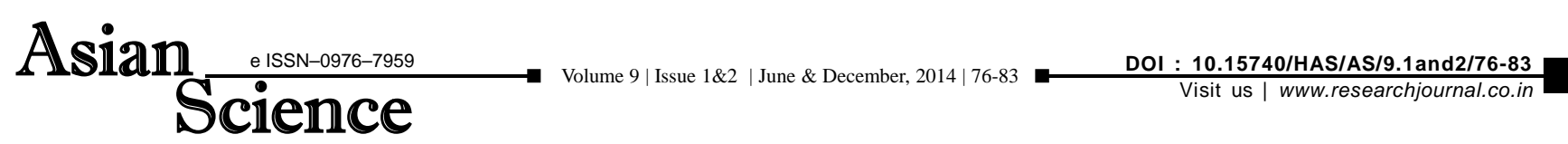

A REVIEW

\title{
TV viewership and rural women
}

\author{
DIPPANJEET KAUR* AND SHEETAL THAPAR
}

Department of Agriculture Journalism, Languages and Culture, Punjab Agricultural University, LUDHIANA (PUNJAB) INDIA (Email: sheetal.pau@gmail.com)

\begin{abstract}
Media plays a crucial role in our society with the purpose to inform the public about current and past events and issues of public significance. Television has become one of the most important mass media in the recent years. Originally, seen as a means of entertainment for the young and old, television in the twenty-first century is practically watched by all age groups, including infants. Television has immense capability to substantially benefit all when it is used for awareness generation and for learning purposes. With fast changes in today's life style, changes are seen in TV-viewing habits of women. It is observed that the duration of TV-viewing 'in general' and the 'duration of watching TV alone' have increased for an average audience. The paper is an attempt to gain a deeper understanding of TV viewership and rural women.
\end{abstract}

Key Words : Rural woman's TV viewing pattern, Rural women, TV viewership

View point paper : Kaur, Dippanjeet and Thapar, Sheetal (2014). TV viewership and rural women. Asian Sci., 9 (1\&2): 76-83.

\footnotetext{
* Author for correspondence

Dippanjeet Kaur, Department of Agriculture Journalism, Languages and Culture, Punjab Agricultural University, LUDHIANA(PUNJAB) INDIA(Email: dippanpaulcobsajlc@pau.edu)
} 